\title{
NEW RECORDS OF MARGINAL LOCATIONS FOR AMERICAN PIKA (OCHOTONA PRINCEPS) IN THE WESTERN GREAT BASIN
}

\author{
Constance I. Millar ${ }^{1,2}$, Robert D. Westfall ${ }^{1}$, and Diane L. Delany ${ }^{1}$
}

\begin{abstract}
We describe 46 new site records documenting occupancy by American pika (Ochotona princeps) at 21 locations from 8 mountain regions in the western Great Basin, California, and Nevada. These locations comprise a subset of sites selected from regional surveys to represent marginal, isolated, or otherwise atypical pika locations, and to provide information for assessing environmental tolerance limits. Several locations are known from historic observations (Madeline Plain, Bodie Mtns., Wassuk Mtns., Mono Craters) and are included here to update current status. Site elevations range from $1848 \mathrm{~m}$ to $3392 \mathrm{~m}$; relative to the broad range of pika sites in the region, the new locations have climates that are $2-4{ }^{\circ} \mathrm{C}$ warmer and receive approximately half the annual precipitation. Sites are located in lava flows and domes, inselbergs (isolated, rocky exposures on a small hill), eroding bedrock, rock-glacier till, talus slopes, and anthropogenic roadbed armaments and mining ore dumps. Several sites are situated in uncommon vegetation contexts, for example, montane desert scrub communities or locations where vegetation adjacent to taluses is sparse or lacking. Proximity to surrounding pika habitats (as a measure of marginality) was evaluated based on relative talus distribution patterns for $0.5-\mathrm{km}, 2.5-\mathrm{km}$, and 5.0-km circular areas nested around each site. Seven idealized, schematic spatial patterns were used to assess potential connectivity among sites, ranging from "island" (no other talus within the respective areas) to "even" (many talus patches regularly distributed). Applying this approach to the 21 sites demonstrated a simple method for qualitatively assessing pika habitat relative to dispersal potential and metapopulation viability and also revealed complexities of biogeographic patterns related to marginality.
\end{abstract}

Resumen.-Describimos 46 nuevos lugares donde documentamos la presencia de Pica Americana (Ochotona princeps), en 21 lugares de ocho regiones montañosas en la parte oeste de la Gran Cuenca, California y Nevada. Estos lugares comprenden un subconjunto de sitios que se seleccionaron de investigaciones regionales para representar lugares donde se encuentra esta especie, donde son poco comunes o están aislados, y así dar información con el fin de evaluar sus límites de tolerancia ambiental. Varios lugares se conocen por observaciones históricas (Madeline Plain, Bodie Mtns, Wassuk Mtns, Mono Craters) y los incluimos para actualizar su condición. Las elevaciones de los lugares oscilan entre 1848 m y 3392 m; en relación con la amplia variedad de lugares donde se encuentra la pica en la región, los nuevos lugares tienen temperaturas de 2 a $4{ }^{\circ} \mathrm{C}$ más cálidas y registran aproximadamente la mitad de las precipitaciones anuales. Los lugares están ubicados en ríos y domos de lava, inselbergs (relieves aislados y rocosos sobre una pequeña colina), roca madre erosionada, sedimento glacial-rocoso, taludes rocosas, armamentos en el balasto de origen humano y vertederos de desechos de minería. Varios lugares se encuentran en contextos de vegetación poco común, por ejemplo: comunidades de arbustos montañosos o lugares en los cuales la vegetación contigua a los taludes es escasa o inexistente. Evaluamos la proximidad a los hábitats de pica de los alrededores (como medida de marginalidad) según los patrones relativos de distribución de taludes para áreas circulares de $0.5 \mathrm{~km}, 2.5 \mathrm{~km}$ y $5.0 \mathrm{~km}$ ubicadas alrededor de cada lugar. Utilizamos siete patrones espaciales relativos y esquemáticos para evaluar la posible conexión entre los lugares, desde "aislado" (donde no hay ningún otro talud dentro de las áreas) hasta "regular" (muchas áreas de taludes distribuidas de manera regular). La aplicación de este enfoque a los 21 lugares aportó un método simple para evaluar de manera cuantitativa el hábitat de la pica en relación con el potencial de dispersión y la viabilidad de la metapoblación, y reveló las complejidades de los patrones biogeográficos relacionados con la marginalidad.

American pikas (Ochotona princeps) are small mammals related to rabbits (order Lagomorpha) and are widely distributed in western North American mountains (Smith and Weston 1990). Poor thermoregulation, low dispersal capacity and fecundity, strict habitat specificity, and distinct metapopulation dynamics collectively suggest the species would be vulnerable to climate change. However, in the major western cordillera, such as the Sierra Nevada and Rocky Mountains, pikas persist across diverse environmental contexts and biogeographic conditions (Smith 1974a, Hafner 1994, Millar and Westfall 2010, USFWS 2010, Erb et al. 2011). In the Great Basin, by contrast, pika populations appear to be in sharp decline as a result of changing 20th-21st century climates (Beever et al. 2003, 2010, 2011).

${ }_{1}^{1}$ USDA Forest Service, Pacific Southwest Research Station, 800 Buchanan St., W.A.B., Albany, CA 94710.

2E-mail: cmillar@fs.fed.us 
To better understand species vulnerability, attention has focused on populations at climatic thresholds and range-distribution limits, and on isolated and other marginal locations (Beever et al. 2003, 2011, Simpson 2009, Millar and Westfall 2010, Rodhouse et al. 2010, Manning and Hagar 2011, Henry et al. 2012, Calkins et al. 2012). Temperature limits have been studied most often: in the Great Basin, Smith (1974a) estimated a summer maximum temperature of $22.8^{\circ} \mathrm{C}$ to be a warm limit for pikas, whereas others have shown that chronic stress over 28 ${ }^{\circ} \mathrm{C}$ contributes to rapid population extirpation (Beever et al. 2010, Wilkening et al. 2011). Precipitation also limits persistence: Beever et al. (2008) reported significant differences in annual precipitation between extant and extirpated sites, and the role of growing-season precipitation has been shown to be an increasingly significant correlate of persistence/extirpation after 1990 (Beever et al. 2013). Elevation also has been used as a proxy for climatic thresholds: in the west central Great Basin, $2500 \mathrm{~m}$ has been considered a low-elevation limit for pika persistence (Smith and Weston 1990, Beever et al. 2011), although observations of lower sites have been reported (Beever 2002, Beever et al. 2008, Millar and Westfall 2010, Collins and Bauman 2012). In the southern portion of their Great Basin studies, Beever et al. (2013) observed upslope retraction from the lower-elevation boundary on south-facing slopes, increasing in importance after 1990. Limits to pika distribution and population viability also have been studied in regard to site isolation, dispersal environments, and amount of talus area (Smith 1974b, Peacock 1997, Meredith 2002, Grayson 2005, Stewart and Wright 2012).

We report new records in the western Great Basin of sites currently occupied by pikas and occurring at climatic, habitat, and geographic margins. Our goal is to describe the biogeographic contexts of these sites and characterize their marginality. We offer a simple framework for classifying geographic patterns of sites and describe locations that could prove useful in future studies on factors regulating pika metapopulation persistence.

\section{METHODS}

During the course of regional inventories of pika sites in the western Great Basin (Millar and Westfall 2010 and subsequent surveys), we visited potentially suitable but marginal locations and assessed their occupancy in the summers of 2011 and 2012. Nomenclature used in this report is as follows: "location" refers to the geographic context; "patch" refers to a local area of pika habitat, such as talus, lava flow, or rocky exposure; and "site" refers to the individual occurrence record (interpreted as a single pika territory), identified by one to several adjacent hay piles and/or pika presence. From our 2010 database ("main database"; Millar and Westfall 2010), we selected locations at low elevations, in arid environments, amidst vegetation communities atypical for the species, or in relative isolation from larger source populations. These locations were chosen based on field knowledge of the range of pika environments in the main database. A site was determined to be occupied if we saw or heard more than one animal during a survey of at least 30 personminutes or if we observed one or more hay piles containing fresh vegetation. Sites were vouchered (pellets collected) and described by latitude, longitude, elevation, coarse vegetation, substrate, and landform. Weather conditions in the winter months prior to the 2011 and 2012 field seasons were strongly contrasting, with the winter of 2010-2011 having record high and persistent snowpacks and the subsequent winter having record low snowpacks. Although differences in abundance were observed in mid- and upper-elevation pika habitats in California (C. Millar unpublished data; R. Klinger, personal communication, 2012), for the locations reported here, we observed pikas in both years with no apparent differences in abundances.

Prior studies have indicated that amount of habitat and proximity to potential habitat are important factors in population viability and persistence, especially in marginal-appearing locations (Smith 1974a, Stewart and Wright 2012). Because it is difficult to assess the location and size of all talus within the proximity of a known site, and because terms such as "remote," "isolated," or "island" are ambiguous, we used a simple approach to characterize spatial patterns following the methods introduced by Fortin and Dale (2005). To implement this approach, we started with a set of 20 idealized, schematic distributions; these included conventional patterns such as 

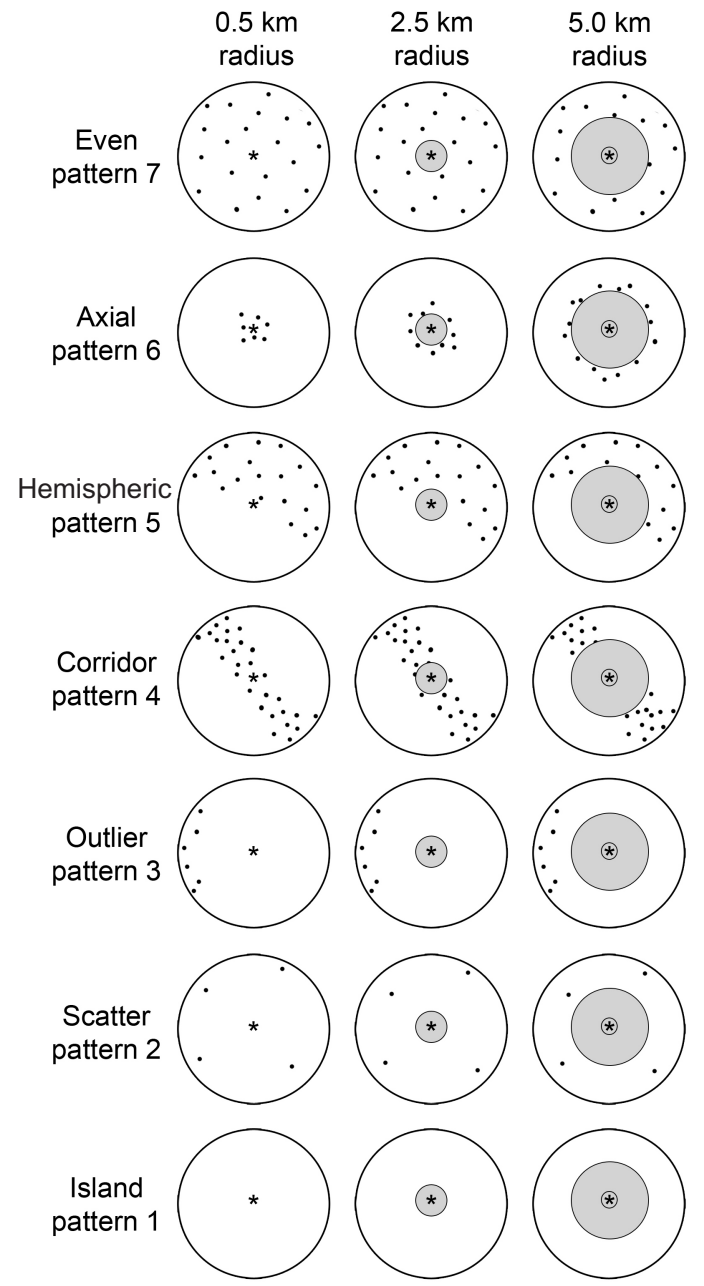

Fig. 1. Schematic diagrams of idealized spatial patterns for talus at 3 scales: $0.5-\mathrm{km}, 2.5-\mathrm{km}$, and $5.0-\mathrm{km}$ radius. Circular areas for each scale are centered on occupied pika sites, indicated by asterisks, and dots represent talus patches adjacent to the pika site. Seven distribution patterns grade from dense and abundant ("even”) to solitary ("island"). Scores for each occupied site (Table 2) were assessed independently for each scale. Shaded zones in the middle (2.5-km radius) and right $(5.0-\mathrm{km}$ radius) columns indicate areas that were sequentially excluded for scoring at each scale.

random, uniform, and clumped, as well as patterns derived from observed distribution of talus patches in diverse pika environments. To address known relationships of pika territories, talus patches, and pika dispersal distances, as well as the metapopulation behavior of the species (Smith and Gilpin 1997), we used a hierarchic approach to score distribution patterns at 3 nested scales of circular areas centered on the pika site and having $0.5-\mathrm{km}$, 2.5-km, and 5.0-km radii (Fig. 1).

High-resolution Google Earth imagery was used to locate talus patches around sites. Using the ruler tool, we drew radii at the 3 scales and then outlined perimeters of 3 nested circles centered on the mapped pika site. At each scale, we visually estimated the distribution of talus patches against the 20 candidate patterns. Because patterns can differ at each scale, the scores were made independently; that is, scores were separately assessed for each zone around the known-occupied site (i.e., the inner circle of $0.5-\mathrm{km}$ radius, the middle zone from $0.5-\mathrm{km}$ to 2.5 - $\mathrm{km}$ radius, and the outer zone from $2.5-\mathrm{km}$ to $5.0-\mathrm{km}$ radius). After scoring all sites and zones using the preliminary set, we found 7 patterns that effectively describe relationships for all sites and scales (Fig. 1). The final set of scores for each site allowed comparisons of the relative geography among locations.

To estimate and compare climates for locations of the occupied sites, we used the PRISM climate model (30 arc-sec [ $\sim 800 \mathrm{~m}$ ] grids, 1971-2000) to extract mean minimum and maximum temperatures for each year and for June and July of each year. We also extracted annual precipitation (Daly et al. 1994; http://prismmap.nacse.org/nn/). We compared these data with the frequency distribution of climate data from our main database of pika site locations where the locations had been intersected with PRISM 30 arc-sec grids in GIS (Millar and Westfall 2010). To summarize the relationship of the marginal locations with the main database in joint climate space, we ordinated the climate data in canonical analysis, using mountain range as the classifying (categorical) criterion. The frequency distribution and canonical analyses were done in the Distribution and Discriminant platforms, respectively, in JMP (SAS Institute, Inc. 2010).

\section{RESUlTs}

\section{Site Descriptions}

Twenty-one locations, comprising 46 occupied and pellet-vouchered pika sites, are reported here (Fig. 2, Table 1). These extend from the Madeline Uplands, Lassen County, northern California, to the eastern White Mountains, Inyo County, southern California. Elevations ranged from $1848 \mathrm{~m}$ to $3321 \mathrm{~m}$, aspects 


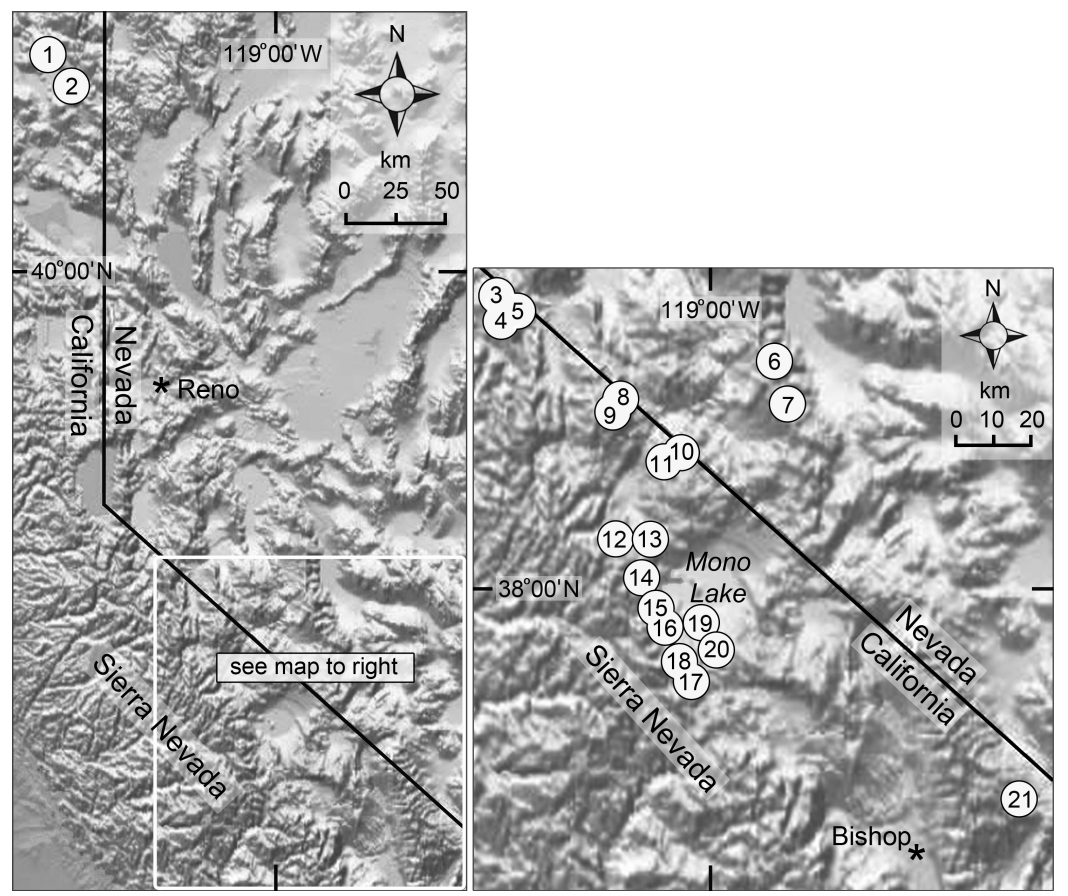

Fig. 2. Map of 21 locations of 46 occupied marginal occurrence sites of American pika in northeast California (large map) and the central western Great Basin (inset).

were diverse, and substrates included lava flows, volcanic domes, metamorphic and granitic taluses, rock-glacier till, inselbergs, and eroding bedrock slopes. Four sites were anthropogenic, including 2 rockslides below roads and 2 mining ore dumps. Ordination showed that many of the new sites lie at the edges of, or outside the range of, climate envelopes for the relevant mountain regions from the main database (Fig. 3). Other sites lie closer to the climatic distribution in a mountain range other than the local range. Still others do not reflect marginality in climate space, yet they occur at geographic margins and/or within uncommon vegetation communities for pika habitats in the western Great Basin. Each location is summarized below (refer to Figs. 1-3, Tables 1-3).

Madeline Uplands.-Two locations, each having multiple sites, were observed to be occupied by pikas in the Madeline Uplands above Madeline Plain, MacDonald Peak (2421 $\mathrm{m})$ and Observation Peak (2434 m). These volcanic cones are the tallest peaks bordering the playa of Pleistocene Lake Madeline (Bowers 2009), which has a base elevation of $1616 \mathrm{~m}$.
The pika sites occur in talus of lava flows, which are exposed abundantly along the southern slopes and the high northern slopes of both peaks. Occupied sites ranged from 1848 m (MacDonald Peak, Fig. 4) to 2388 m (Observation Peak). Patch sizes were relatively large $(\bar{x}=0.15 \mathrm{ha})$, and the distribution patterns were linear at the local scale ("corridor") and one-sided ("hemispheric") at greater distances from the site. At the scale of large pika metapopulations (e.g., 5-km radii), abundant talus exists.

Old-growth sagebrush steppe dominated by sagebrush (Artemisia spp.), bitterbrush (Purshia tridentata), rabbitbrush (Ericameria spp.), and Ephedra shrub species with a barren understory surrounded the upper pika sites on MacDonald Peak. In contrast, a recent fire on the lower slopes had stimulated dense regrowth of diverse graminoids and herbaceous species adjacent to the taluses. Pikas were observed more often and more fresh hay piles were tallied in talus patches of the lower fireburned region than on the unburned upper slopes. Similar vegetation (sagebrush steppe) surrounded pika sites and talus patches on 


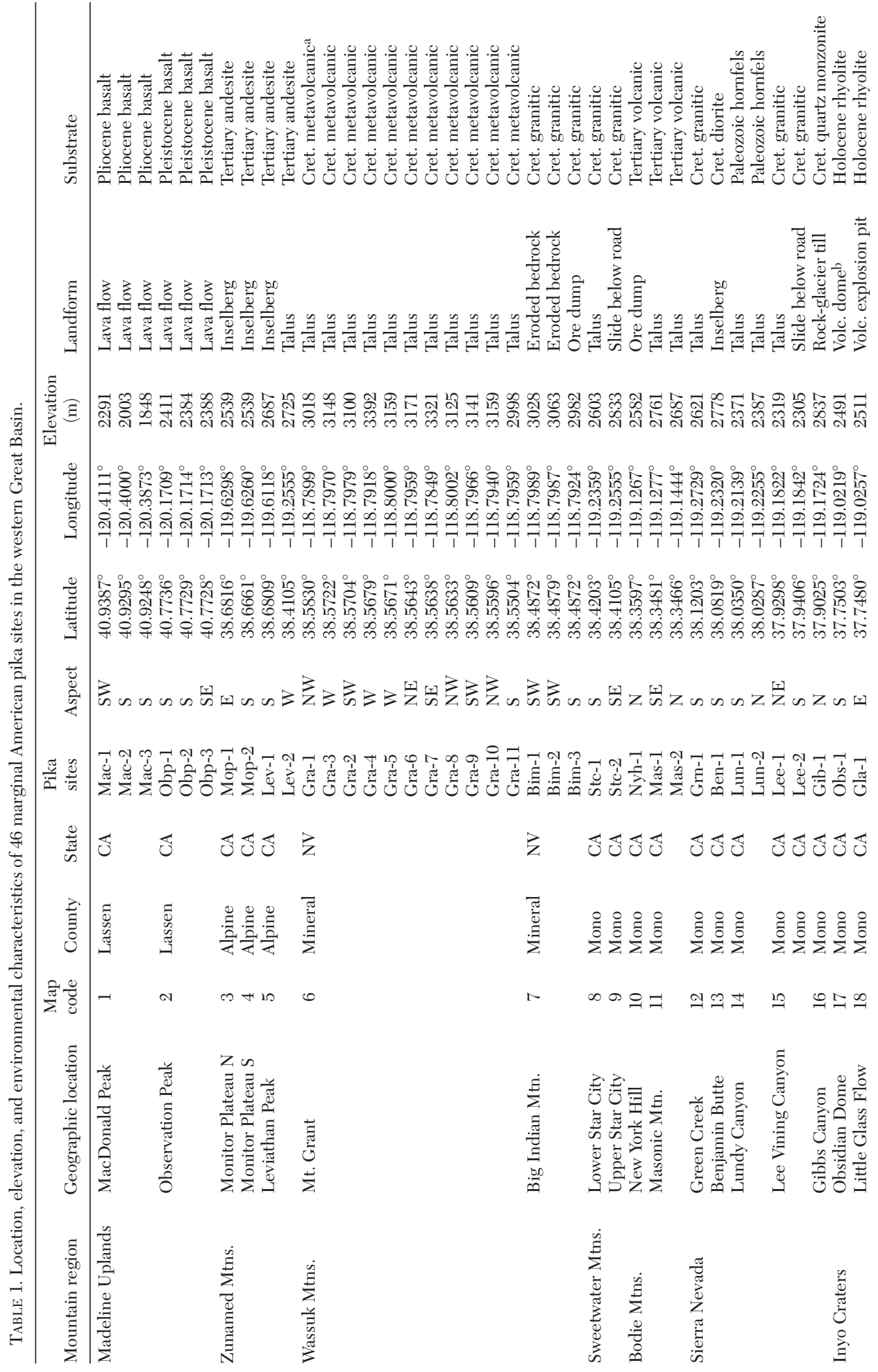




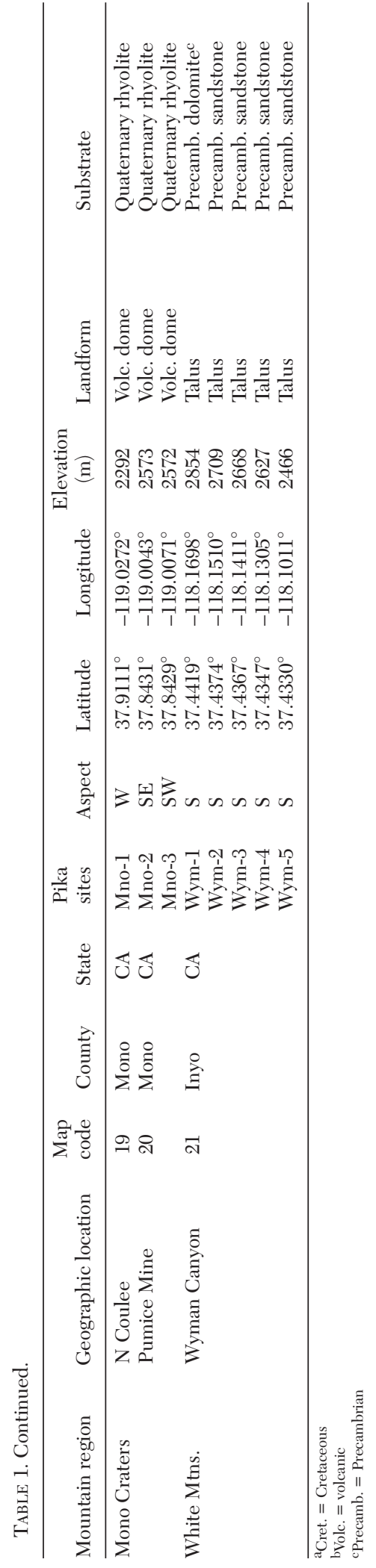

Observation Peak, although mountain mahogany (Cercocarpus ledifolius) and shrubby aspen (Populus tremuloides) were also present. A recent and extensive fire on Observation Peak had similarly stimulated growth of diverse forbs and graminoids, which were abundantly represented in hay piles.

PRISM-modeled estimates of late 20thcentury climate indicate the Madeline Uplands to be the warmest of the locations described in this report in almost every measure. The uplands are also the driest locations, receiving only about half the average annual precipitation of all locations. In relation to the main pika database, the uplands are in the lower $10 \%$ of the distribution in precipitation and in the upper $2.5 \%$ in maximum and minimum temperatures. In the canonical ordination (Fig. 3), the Madeline Uplands were an outlier, occupying the warmest extreme of the ordination and being well outside the $90 \%$ concentration ellipsoids of the 4 reference mountain ranges.

The occurrence of a historic record of pikas at $1640 \mathrm{~m}$ on the Madeline Plain (Howell 1924) prompted several attempts to relocate this site, as well as to survey potential habitat in the proximity. Howell's information is scant, but given his description ("near Termo, CA") and the elevation just above the playa base level, the only apparent location are the volcanic taluses on small and low Termo Buttes $(1666 \mathrm{~m})$, which lie near the middle of the northwest lobe of Madeline Plain about $3 \mathrm{~km}$ west of Termo. The talus patches (1640-1680 m) are exposed above wave-cut terraces of the Pleistocene lake. Three separate surveys were made of the Termo Buttes during 2011 and 2012. From these, only one putative and very old hay pile was found, and because this might well have been an old Neotoma nest, we do not consider that location to have definite pika sign. Despite its lower elevation and location in the midst of the playa, PRISMmodeled estimates indicate temperatures similar to the occupied MacDonald Peak sites, although annual precipitation is $45 \mathrm{~mm}$ less at Termo Buttes.

In contrast to the Termo Buttes, we have found definite but old pika hay piles and relict pika pellets in the abundant volcanic taluses on the southern slopes of nearby Three Peaks, north and east of Termo. These relict sites extend from $1825 \mathrm{~m}$ to $1924 \mathrm{~m}$ (Millar and 


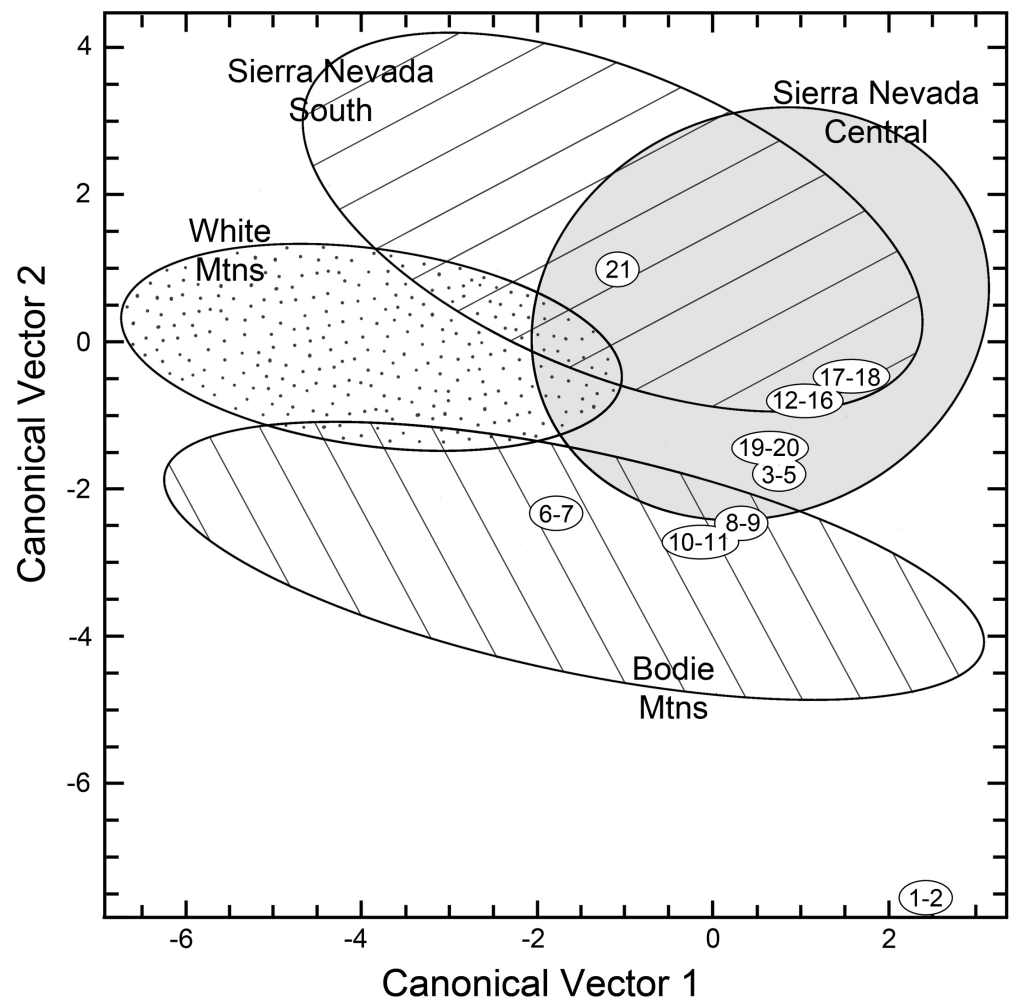

Fig. 3. Plot of mean climatic canonical scores of marginal sites by mountain range relative to 4 ranges from the main database (Millar and Westfall 2010). Numbers in circles refer to marginal site locations described in Table 1. Scores are standardized to a mean of 0 and a within-mountain range standard deviation of 1 . Ninety percent concentration ellipsoids are shown for ranges in the main pika database with more than 15 sites. The first canonical vector $(\mathrm{CV})$ is positively correlated with precipitation and minimum temperatures, and the second CV is positively correlated with precipitation and negatively correlated with maximum temperatures. These first $2 \mathrm{CV}$ s describe $75 \%$ of the variation among mountain ranges.

Westfall 2010); radiocarbon assessments show these to be many decades old, dating to the 1950s. For the northern Madeline Plain location, in sum, we have found occupied pika sites only on MacDonald Peak, where the sites extend from low elevation to the summit, and on Observation Peak, where we have explored only the summit region.

Zunnamed Mtns.-This unnamed Great Basin upland (cataloged as Zunnamed Mtns. by Nevada biogeographer David Charlet, personal communication 2010) rises as a discrete, small range east of Ebbetts Pass, Sierra Nevada; the range is isolated on its north, east, and west flanks by broad lowland basins. Pikas are abundant on the scattered and small volcanic inselbergs of Monitor Plateau and throughout clusters of slope taluses of the highest peaks of the Zunnamed Mtns. (2531-2725 m).
Described here are 3 representative sites on the north and south ends of the plateau and on Leviathan Peak.

The 2 plateau sites are small volcanic inselberg islands, with very limited talus areas (mean patch sizes $0.07 \mathrm{ha}$ ), and are surrounded by extensive sagebrush steppe and open pinyon pine (Pinus monophylla) woodland. At each of the 3 scales of distribution, these sites scored as isolated habitat ("scattered”). Talus patches on Leviathan Peak, by contrast, are much larger (0.44 ha) and appear to serve as source habitat for the scattered small patches on the plateau. This is corroborated by the patterns of distribution at the 3 scales for Leviathan Peak, which show abundant talus distributed broadly out from the peak. Fresh hay piles were abundant at all recorded locations; these were more densely 
TABLE 2. Geographic relations of pika sites to adjacent talus area. Circular areas around pika sites at 0.5- $\mathrm{km}, 2.5-\mathrm{km}$, and $5.0-\mathrm{km}$ radii were scored by distribution patterns shown in Figure $1.1=$ island, $2=$ scatter, $3=$ outlier, $4=$ corridor, $5=$ hemispheric, $6=$ axial, $7=$ even.

\begin{tabular}{|c|c|c|c|c|c|}
\hline Mountain region & Geographic location & $\begin{array}{c}\text { Patch size } \\
\text { (ha) }\end{array}$ & $\begin{array}{l}0.5-\mathrm{km} \\
\text { radius }\end{array}$ & $\begin{array}{l}2.5-\mathrm{km} \\
\text { radius }\end{array}$ & $\begin{array}{l}5.0-\mathrm{km} \\
\text { radius }\end{array}$ \\
\hline \multirow[t]{2}{*}{ Madeline Uplands } & MacDonald Peak & 0.14 & 4 & 5 & 5 \\
\hline & Observation Peak & 0.16 & 5 & 5 & 4 \\
\hline \multirow[t]{2}{*}{ Zunnamed Mtns. } & Leviathan Peak & 0.44 & 5 & 2 & 2 \\
\hline & Monitor Plateau & 0.07 & 2 & 2 & 2 \\
\hline \multirow[t]{2}{*}{ Wassuk Mtns. } & Mt. Grant & 0.29 & 7 & 2 & 2 \\
\hline & Big Indian Mtn. & 0.01 & 2 & 2 & 2 \\
\hline \multirow[t]{2}{*}{ Sweetwater Mtns. } & Lower Star City & 0.01 & 1 & 3 & 5 \\
\hline & Upper Star City & 0.16 & 1 & 5 & 5 \\
\hline \multirow[t]{2}{*}{ Bodie Mtns. } & New York Hill & 0.02 & 6 & 2 & 2 \\
\hline & Masonic Mtn. & 0.10 & 4 & 2 & 2 \\
\hline \multirow[t]{5}{*}{ Sierra Nevada } & Green Creek & 3.12 & 4 & 5 & 5 \\
\hline & Benjamin Butte & 0.03 & 1 & 3 & 5 \\
\hline & Lundy Canyon & 1.10 & 4 & 5 & 5 \\
\hline & Lee Vining Canyon & 0.85 & 3 & 7 & 5 \\
\hline & Gibbs Canyon & 0.23 & 7 & 5 & 5 \\
\hline \multirow[t]{2}{*}{ Inyo Craters } & Obsidian Dome & 0.30 & 7 & 2 & 2 \\
\hline & Little Glass Flow & 0.13 & 3 & 2 & 2 \\
\hline \multirow[t]{2}{*}{ Mono Craters } & N Coulee & 2.60 & 7 & 6 & 2 \\
\hline & Pumice Mine & 2.10 & 5 & 5 & 4 \\
\hline White Mtns. & Wyman Canyon & 0.02 & 4 & 7 & 5 \\
\hline
\end{tabular}

distributed (3-5 $\mathrm{m}$ apart within talus patches) than is typical in higher montane environments. We have found only Neotoma sign, and no pika sign, below $\sim 2200 \mathrm{~m}$ in talus patches of the south slope of this range.

PRISM-estimated temperatures of the Zunnamed Mtn. pika sites corroborate a more continental climate influence and reflect the relatively higher elevations compared to other locations recorded: minimum and maximum temperatures were among the coldest seasonally and annually. Nonetheless, annual maximum temperature of the Zunnamed sites was in the upper $25 \%$ and January minimum temperature in the upper $10 \%$ of the pika main database. In the ordination, the Zunnamed sites positioned near the Mono Craters. Estimated annual precipitation was high, second only to the Inyo Craters sites.

WASSUK MTNS.-This high-elevation range extends from the Anchorite Hills near the CA-NV border of the northeast Mono Basin northward $75 \mathrm{~km}$, dividing the East Walker and Walker Lake basins. Pikas are abundant throughout the extensive metavolcanic and granitic taluses of the highest peaks; 11 representative sites (ranging from $2982 \mathrm{~m}$ to $3321 \mathrm{~m}$ ) are described on the Mt. Grant massif and 3 on Big Indian Mtn.

On the broad flanks of Mt. Grant, talus exposures occur as periglacial landforms, flowing downslope as sorted stripes (sensu French 2007) and forming large talus habitats (patch sizes $0.29 \mathrm{ha}$ ). Elsewhere, as on Big Indian Mtn., pika habitat occurs as very small patches (0.01 ha) of eroding granitic bedrock. These geomorphic differences are reflected in the scores of talus distribution pattern at the 3 scales: the Mt. Grant sites show high connectivity and density of patches at small distances $(0.5-\mathrm{km}$ radii), with isolation at the larger scales, whereas the Big Indian Mtn. sites are sparse and isolated ("scattered") at all scales. Vegetation surrounding the pika habitat ranges from sagebrush steppe, dominated by giant sagebrush (Artemisia tridentata) at lower elevations, to prostrate alpine sage communities at higher elevations. PRISM-estimated mean temperatures are, as expected for the high elevations, among the coolest of the new sites and have much lower annual precipitation than comparable elevations in the Sierra Nevada. The position of the Wassuk Mtns. in joint climate space is within the Bodie Mtns. ellipsoid and between the means for the Bodie Mtns. sites and the Sweetwater Range.

Pikas were observed historically on Big Indian Mtn. in 1947 (University of California specimens, cited in Beever et al. 2003), and Big Indian Mtn. was documented as occupied during subsequent visits from 1994 to 2011 (Beever et al. 2003, 2010, 2011). Although 


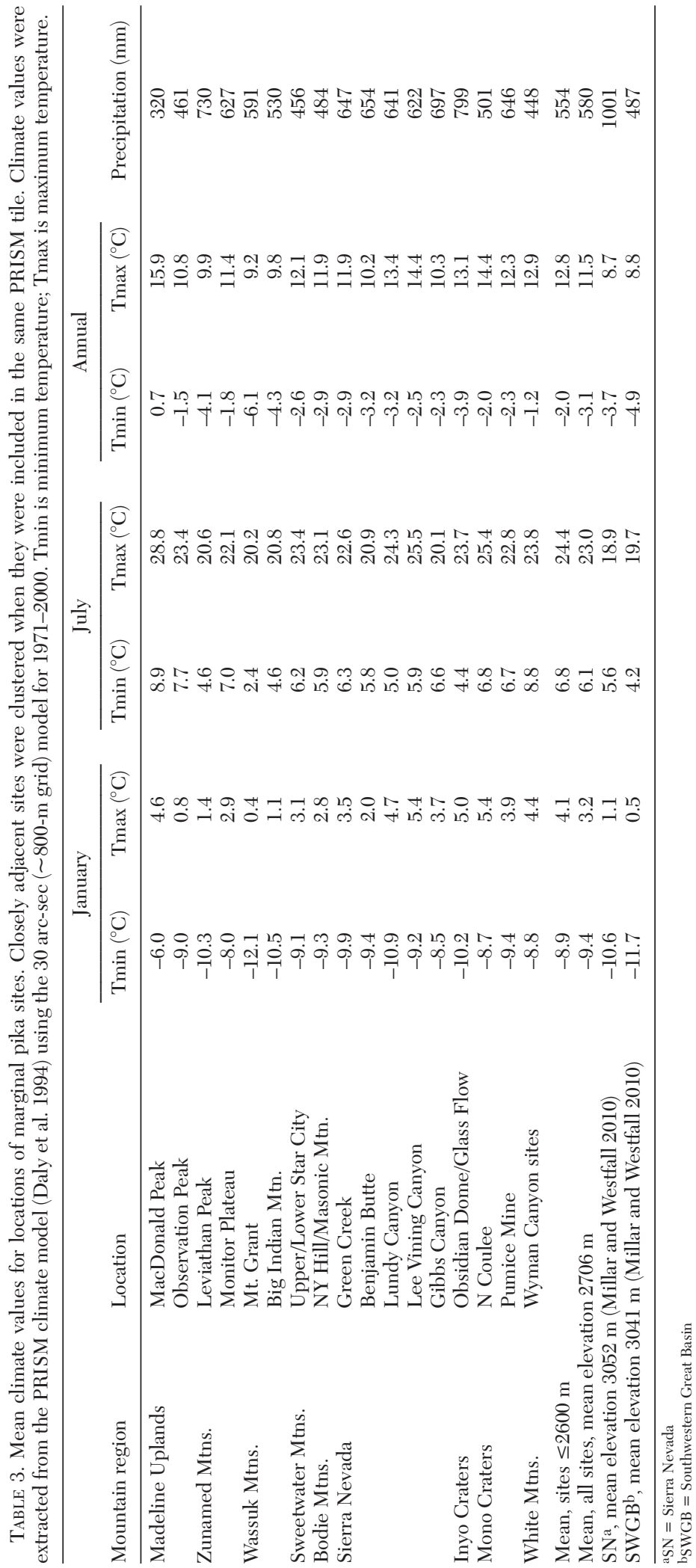




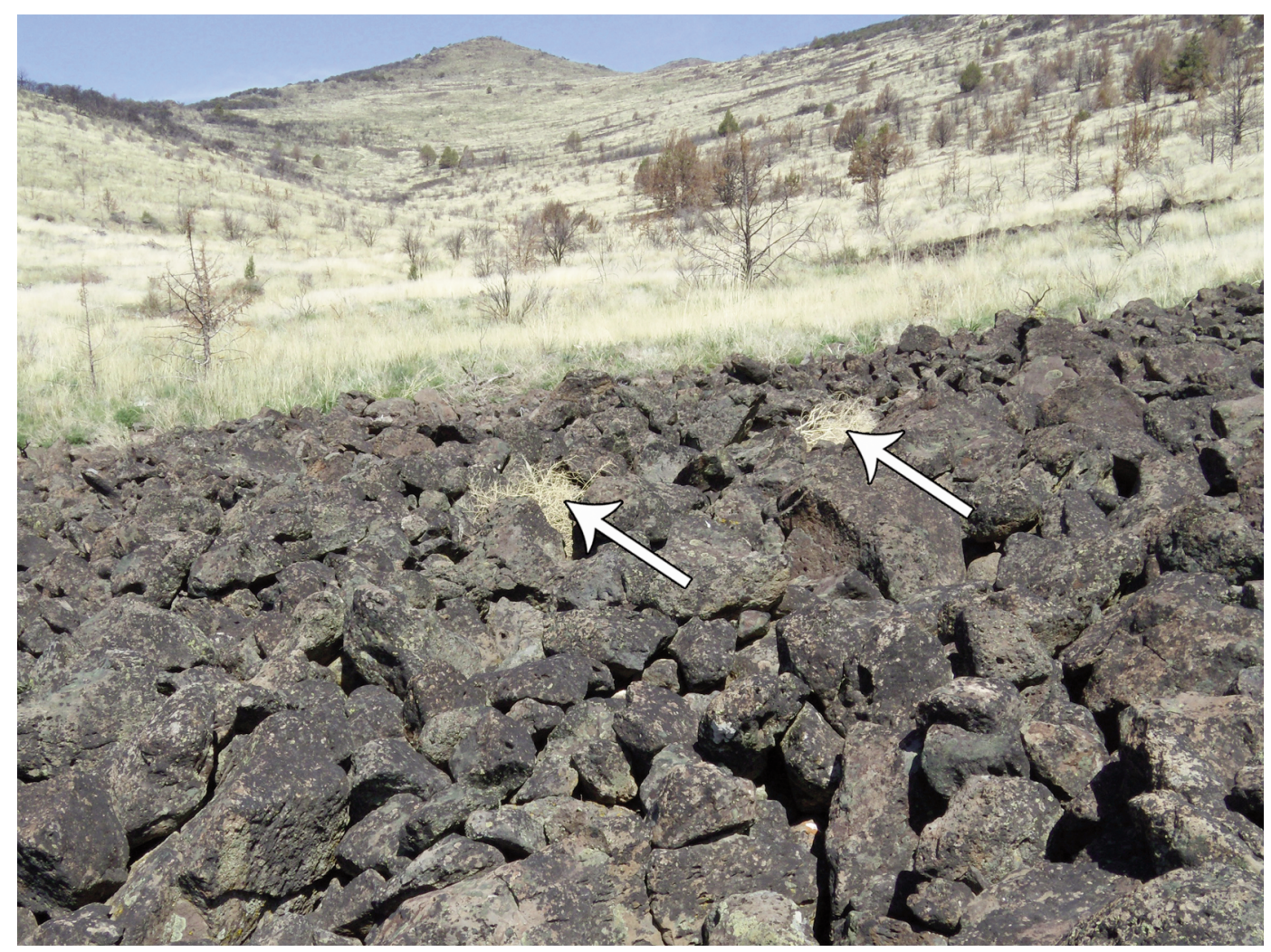

Fig. 4. MacDonald Peak, Madeline Uplands pika site. Note 2 hay piles in the talus (at arrows) and regrowth of perennial grasses following a recent fire in the lowland regions. View is northwest.

patches are small and scattered at the geographic scales assessed, they apparently support a long-persisting metapopulation.

Sweetwater Mtns.-The Sweetwater Mtns. are a small, isolated range east of the Sierra Nevada and north of Bridgeport, California, with summit elevations to $3565 \mathrm{~m}$ and an extensive plateau area above $3000 \mathrm{~m}$. Substrates are highly varied across the range and support a hotspot of plant diversity that represents complex Sierra Nevada and Great Basin affiliations (Lavin 1983), with a significant component of rare and endemic species. The range had minor Pleistocene glaciation, which carved cirque canyons with associated taluses on the east and north slopes; several rock glaciers remain active. Periglacial activity has created abundant but scattered talus patches and other sorted rock landforms in the range. Previous reports of occupied pika sites in the range focused on the west slope (Millar and Westfall 2010); high-elevation occupied sites on all major aspects have since been mapped (Millar unpublished inventory). Here we report 2 marginal locations on the east slope of the range. These appear as isolated and lowelevation talus patches $(\bar{x}=2718 \mathrm{~m})$, east of and below Mt. Wheeler in the vicinity of the mining-era settlement of Star City.

The Lower Star City site is a tiny patch of native talus on a flat-south aspect $(0.01 \mathrm{ha})$. It lies in the pinyon pine-Utah juniper (Juniperus osteosperma) woodland zone, with relatively barren pine stands on one flank and a dry sagebrush-steppe plain on the other. Two pikas were observed in this patch, as well as 2 large fresh hay piles. In addition to sagebrush, bitterbrush (Purshia tridentata), and graminoids, the hay piles contained foliage from species less commonly observed in hay piles, including Utah juniper, Mormon tea (Ephedra viridis), rabbitbrush (Ericameria nauseosa), mountain mahogany, mule-ears (Wyethia mollis), and prickly phlox (Linanthus pungens). 


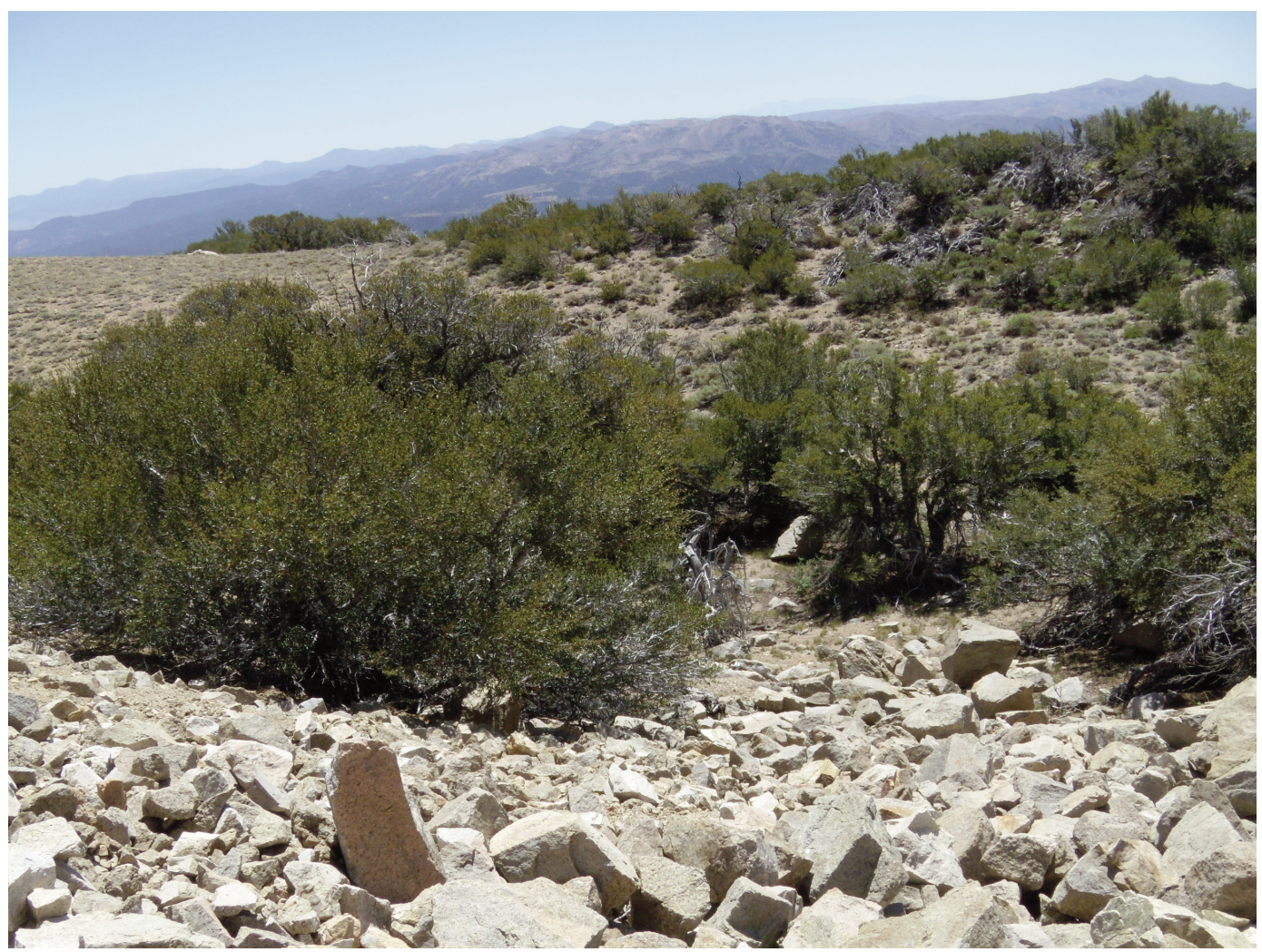

Fig. 5. Upper Star City, Sweetwater Mtns. pika site. This anthropogenic site derives from erosion below a dirt road on the slope above the talus. Mountain mahogany and scattered sagebrush-steppe species are in the foreground; Bodie Mtns. (right) and Wassuk Mtns. (left) are in the background. View is southeast.

The Upper Star City location is a rockslide that formed on a steep southeast slope as erosion from the dirt road that leads to the historic mining town of Belmont. It is $1.5 \mathrm{~km}$ distant from the lower site and, despite its slightly higher elevation, has more arid exposure. The base of the rockslope is dominated by small mountain mahogany trees, with beavertail cactus (Optuntia basilaris) and sparse rabbitbrush in the otherwise barren and sandy talus front (Fig. 5). These species occurred in 5 fresh hay piles observed on this patch.

Scoring the distribution of taluses adjacent to these sites demonstrated the effect of isolation and connectivity at different scales. Though each of these sites lies in a solitary talus island at the smallest radius $(0.5 \mathrm{~km})$, at each of the larger scales, more abundant patches are evident, all in the upslope direction ("hemispheric"). At the largest scale (5.0$\mathrm{km}$ radius), extensive habitat was distributed along the subalpine and alpine slopes of the east flank of the range. These are likely source populations for outlier sites such as the 2 described. PRISM estimates of temperature indicate this location to be within the range of values for other locations in this report. In relation to the main pika database, the Sweetwater sites are in the lower $10 \%$ in precipitation and upper $10 \%-25 \%$ in temperature, and are positioned at the warm and dry end of the Bodie Mtns. ellipsoid.

Bodie MTns.-The Bodie Mtns. are a small, isolated upland range east of the Sierra Nevada and south of the Sweetwater Mtns., from which they are separated by the Bridgeport Basin and truncated on the south by the Mono Basin. Summits are lower than other pikaoccupied ranges in this region, cresting at $3100 \mathrm{~m}$, with much of the range in a broad upland plateau averaging $2600-2700 \mathrm{~m}$. The Bodie Mtns., and the Bodie Mining District 


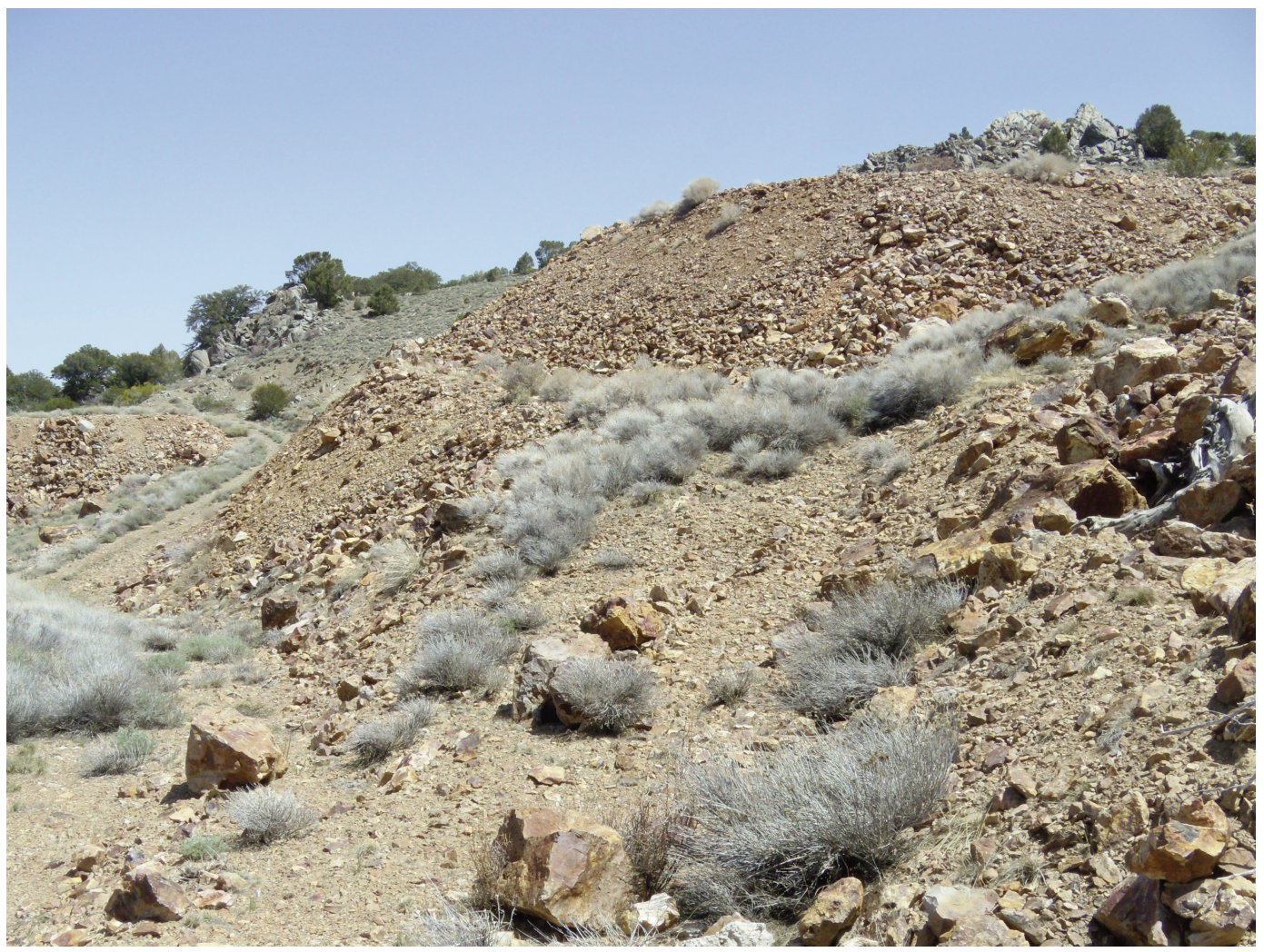

Fig. 6. New York Hill, Bodie Mtns. pika site. Occupied sites are distributed in the coarse-fragment sections of ore dumps at Serita Mine. View is northeast.

in particular, have been the subject of intensive, multidecadal pika studies led by Andrew Smith.

We describe 2 locations $(\bar{x}=2677 \mathrm{~m})$ at the north end of the Bodie Mtns. One is a set of anthropogenic ore dumps on north aspects of New York Hill at Serita Mine, above the townsite of Masonic (Fig. 6). The small dump habitats (0.02 ha) are similar in distribution although less extensive than the well-studied Bodie District. In 1972, Andrew Smith observed abundant pika activity in ore dumps of Serita Mine (Smith, personal communication, 2010); Nichols (2009) documented extirpation at the ore dumps of this same historic mining site prior to 2008. This general region is within a pinyon pine-mountain mahogany woodland community often considered too xeric to support pika forage. The mine site is locally surrounded by sagebrush-steppe shrubland, with rabbitbrush, Artemesia spp., and graminoids dominating areas adjacent to the ore dumps. Beavertail cactus and Mormon tea occur scattered along the borders as well. Fresh hay piles, dominated by perennial grasses and rabbitbrush, and pikas were observed and heard in 2011 and 2012. In 2012, five animals were spotted following an overhead flight of ravens, whose presence elicited a chorus of pika calls throughout the ore dump region.

The other location reported for the Bodie Hills is Masonic Mountain. Occupied sites are dotted along the north and south slopes of the summit ridge at east and west ends. We include 2 sites having a mean elevation of $2724 \mathrm{~m}$; the westernmost site is $2.5 \mathrm{~km}$ distant from New York Hill and rises above the old Chemung Mine. These native taluses comprise eroding bedrock with minimal talus landform. These are scattered along the slopes of the mountain (0.1 ha mean patch size), and pika sign (pellets, fresh hay piles, calls) and animals were observed where the rocky slope 
forms habitat with the greatest abundance of rocks relative to soil or vegetation. Sagebrushsteppe vegetation surrounds the pika sites, dominated by Artemisia spp., bitterbrush, and rabbitbrush, with Ribes spp., mountain mahogany, and graminoids co-occurring in lesser abundance. The western constellation of patches lies $\sim 160 \mathrm{~m}$ above the ore dumps of Chemung Mine, where abundant relict sign exists but no indication of occupation has been observed for at least the past 5 years. The Masonic Mtn. populations of pikas are likely the source area for the marginal sites at New York Hill and, during more favorable conditions, likely also provided the source for the ore dumps at Chemung Mine.

Both locations described here comprise locally dense clusters of talus patches, as shown by the distribution assessment of taluses adjacent to the documented sites. In particular, the cluster of ore dumps at New York Hill affords abundant habitat with patches in close proximity to one another. For larger areas around these sites, however, relative remoteness is documented as "scattered" patterns. Positioned near the Sweetwater locations in climate space, the Bodie locations fell in the lower $25 \%$ of the precipitation distribution and upper $10 \%-25 \%$ of the temperature distribution relative to the main database.

SierRa Nevada.-The massive cordillera of the Sierra Nevada contains the primary core of pika habitat in California (Smith and Weston 1990). In recent years, occupied sites have been surveyed across broad elevation ranges (Moritz et al. 2008, Millar and Westfall 2010, CDFG 2013). In the central Sierra Nevada, a majority of these sites were above 2500 $\mathrm{m}$, an elevation historically considered to be low. Here we describe marginal locations from 5 regions.

Green Creek is the farthest north of these locations. Many occupied pika sites occur up-canyon throughout the abundant taluses of the steep slopes and ridges. The marginal site lies at midslope on the left-lateral (south aspect) piedmont moraine of the main canyon about $2 \mathrm{~km}$ east of the escarpment front. Talus patches occur in a linear pattern along a foss (intermorainal zone) between 2 moraine stages; thus, although the band is narrow, talus patches are relatively continuous (patch size 3.12 ha, largest of all sites). This location is not unusually low for pikas (2621 m), but the vegetation community and location of the talus distant from the escarpment are uncommon for occupied Sierran sites. We have found no occupied sites farther east in this region, a result likely related to the diminishing amount of talus. Pikas were abundant along this band of talus, as were green hay piles. Vegetation along the moraine is sagebrush steppe, and hay piles reflect the common shrub, graminoid, and herb species of this community. Despite apparent isolation of the Greek Creek site from the extensive talus up-canyon, the talus distribution at 3 scales showed the site to be well connected to presumed source populations and to have abundant local talus area.

The Benjamin Buttes comprise a small, isolated group of late Mesozoic diorite exposures at the eastern edge of a broad north/south terrace (mean elevation $2740 \mathrm{~m}$ ) that flanks the eastern Sierran escarpment between Virginia Canyon and Green Creek Canyon. Periglacial action and surface erosion at the buttes have resulted in small talus aprons (mean patch size of $0.03 \mathrm{ha}$ ) around large bedrock-core inselbergs. We have observed abundant fresh pika sign and animals on diverse aspects during annual visits since 2008, although Nichols (2009) maps the pika as extirpated before 2008. Only one representative site on a south aspect is included ( $2778 \mathrm{~m}$ ) here. Vegetation surrounding the Benjamin Buttes is sagebrush steppe; however, scattered upland conifers extend downslope (lodgepole pine, Pinus contorta) and upslope (whitebark pine, Pinus albicaulis), aspen is dense on the lower side of the Buttes, and a small wet meadow dominated by Iris missouriensis extends to the west. The isolated nature of this location is indicated by the lowest score ("island") at the $0.5 \mathrm{~km}$ radius scale, an "outlier pattern" at the $2.5-\mathrm{km}$ scale, and connectivity to the Sierran mainland ("hemispheric") at the $5.0-\mathrm{km}$ scale.

As is the situation for most of the Sierran locations, the Lundy Canyon location in the northern Mono Basin represents an eastern and low-elevation site, beyond the edge of the escarpment and situated on the slope of the piedmont moraines, including both north and south aspects. In Lundy Canyon, taluses extend farther eastward on the left-lateral moraine (south aspect), but we have not found pika occupying taluses east of the recorded sites, although old sign exists. Both north- (granitic) and south-facing (metamorphic) ridges 
contain periglacial slope taluses that extend broadly upslope (patch size $1.10 \mathrm{ha}$ ) and occur as increasingly disjunct patches along the lower canyon walls. The lower and southaspect site $(2371 \mathrm{~m})$ has abundant pikas along the perimeter of the talus and throughout the midslopes. Sagebrush steppe with scattered Jeffrey pines (Pinus jeffreyi), as well as lodgepole and pinyon pines, surround the lower site. The hay piles comprise predominantly sagebrush and rabbitbrush mixed with the common forbs. They also frequently include yellow flowerheads of sulphur buckwheat (Eriogonum umbellatum), which, as occasionally seen elsewhere, are not consumed but are scattered for unknown reasons on hay piles. The upper (north aspect) talus patches have lower slope gradient, abut Lundy Lake on its downhill side, and are surrounded by shrubby aspen, which dominates the hay piles. Although both locations lie at or near the present eastern margin of pika occupancy in this canyon, large patch size and continuity with upland taluses are indicated by high scores at all scales for the distribution of habitat. PRISM estimates of climate indicate that, despite proximity to deep and cold Lundy Canyon, these sites are warm in summer and have high mean annual maximum temperature.

Two locations in lower Lee Vining Canyon (mean elevation $2312 \mathrm{~m}$ ), near the west central Mono Basin, are on south and north aspects, both of granitic talus. The former talus derives from erosion below the Tioga Highway (SR $120)$; the other is a talus apron below extensive Pleistocene-age relict rock glaciers that spilled over the right lateral moraines of the canyon. Vegetation around the base of these taluses includes Jeffrey/lodgepole pine and aspen forests with sagebrush steppe directly adjacent to the talus borders. Patch sizes are moderately large $(0.85 \mathrm{ha})$ and, similar to the other Sierra canyon locations, likely represent the easternmost occupied habitat in the canyon. Distribution of patches around the sites is relatively isolated ("outlier"), whereas at increasingly greater distances, connectivity to the extensive montane talus zones of the higher Sierra indicates a "hemispheric" distribution.

The site described at Gibbs Canyon, just south of Lee Vining Canyon, similarly represents a likely easternmost occupied patch in the canyon. Situated at $2837 \mathrm{~m}$ in the broad and flat granitic till of a Pleistocene-age relict rock glacier, the Gibbs Canyon site is higher than all the Sierra sites here reported. This partly reflects the higher setting of the entire canyon and the presence of rock-glacier till, the latter of which fills the canyon bottom rather than the base, having been scoured by typical ice glaciers that existed in the main stems of the canyons described above. The talus comprises blocks of larger clast size than all other sites described, with boulders commonly $>3 \mathrm{~m}$ in diameter. Growing sparsely on the till is a stand of limber pine (Pinus flexilis), with lodgepole, western white pine (Pinus monticola), and whitebark pine intermixed. Shrubby and herbaceous vegetation is rare around the site and includes sagebrush, Woods' rose (Rosa woodsii), and shrubby aspen, all of which were in the hay pile. Pikas are increasingly abundant up-canyon, as talus becomes extensive in the cirque and canyon walls. Patch size is moderate $(0.23 \mathrm{~m})$ and described primarily by areas of smaller clasts that are separated by zones of much larger boulders or islands of forest. The relatively continuous distribution of patches through the rock-glacier till gives a score of highest connectivity ("even" distribution) within the $0.5 \mathrm{~km}$ radius zone, and relatively high connectivity ("hemispheric") to favorable taluses at greater distances, all in upland directions toward the Sierra escarpment. In ordination, the Sierran locations considered together were situated on the warm and dry edge of the main Sierra Nevada climate ellipsoid.

Inyo and Mono Craters. - The Inyo and Mono Craters, located within the Mono Basin, are distinct chains of late Pleistocene through late Holocene rhyolitic volcanoes. The Inyo Craters comprise individual eruptive cones and domes that extend $10 \mathrm{~km}$ in a north-tosouth trend that lies 5-10 km east of the Sierran crest. Northeast of the Inyo Craters, the main Mono Craters extend $15 \mathrm{~km}$ from the south to a northern boundary at Mono Lake and lie 14-18 km distant from the Sierran crest. The Mono Craters is the more massive volcanic chain, comprising overlapping and complexly aligned eruptive centers called coulees (= steep-sided lava flows). The tephras (=volcanic material ejected during eruption) that provide preferred pika habitat-loose slopes of domes with clasts about $0.5 \mathrm{~m}$ in diameterderive from the most recent eruptions, which occurred throughout the volcanic centers of both 
chains $\sim 660$ years ago (Miller 1985). We have not searched the Inyo or Mono Craters thoroughly for pikas, and the locations described likely represent a minimum of actual sites, given our finding of pikas at north and south ends of the range.

At the Inyo Craters, we have been monitoring 2 occupied sites since 2009. One is along the rhyolite-obsidian base of the steep southfacing slopes of Obsidian Dome (2491 m), where the volcanic flow abruptly meets the soil boundary. The favored size class of clasts for pikas occurs at the lower 1-5 $\mathrm{m}$ of the base of the dome (mean patch size $0.30 \mathrm{ha}$ ); pikas are active in this zone, and hay piles also occur there. Less than $1 \mathrm{~km}$ distant and at similar elevation is a very small, unnamed eruption pit (here, Little Glass Flow), in which occurs a small rhyolite dome. Much of the dome is solid rock and unfavorable pika habitat, but small deposits of tephra have accumulated below these cores and pikas are active in them. Pika hay piles also occur in small tephra patches at the periphery of the pit. Patches are small $(0.13 \mathrm{ha})$, as is the entire crater $(0.5 \mathrm{ha})$. Surrounding both Little Glass Flow and the base of Obsidian Dome are open forests of Jeffrey and lodgepole pines intermixed with western white pine. The understory is sparse. Adjacent to Obsidian Dome are occasional sagebrush, bitterbrush, and graminoids; in addition to these, around Little Glass Flow are occasional Ribes spp. and tobacco bush (Ceanothus velutinus) shrubs. Though the distribution of talus habitat is greater at Obsidian Dome than at Little Glass Flow, the relative isolation of both locations is indicated by their low connectivity scores at $2.5 \mathrm{~km}$ and $5.0 \mathrm{~km}$ radius distances ("scattered").

The 2 occupied sites described for the Mono Craters are at the far north (North Coulee) and far south (Pumice Mine) ends of the Mono Craters chain. Both sites are in a volcanic context similar to Obsidian Dome and lie along the base of large coulees where soil development has occurred on adjacent flat ground. The northern location (2292 m, 2.6-ha patch) has a westward aspect and is the lowest elevation of the new records reported in this region. Adjacent to the pika tephra habitat, the predominantly barren forefields support scattered and stunted pines and occasional rabbitbrush and Ribes plants at very low cover. The Pumice Mine location (2572 m) has a southern aspect bordering a well-developed Jeffrey pine forest on the opposite slope; the talus forefields, however, are barren except for occasional sagebrush-steppe shrubs. The linearity of the tephra and the close proximity of coulee patches provide large amounts of potential habitat surrounding both sites, and individual patches are relatively large $(\bar{x}=2.1 \mathrm{ha})$. Although continuity with talus is high within the Mono Craters chain, isolation is significant ("scattered") at the 5.0-km scale; the nearest known occupied pika sites are at Obsidian Dome in the Inyo Craters, $10 \mathrm{~km}$ from the Pumice Mine site.

The Pumice Mine location came to our attention via Andrew Smith, who had observed abundant pikas nearby in 1969 and again in the mid-1990s (Smith, personal communication, 2009). We have monitored this location since 2009 and found high activity every year. Relative to the main database, these sites are cold in winter and hot in summer. Annual precipitation was lower than the Sierran records and more similar to the inland Great Basin sites.

In climate ordination with the main database, the Mono and Inyo Crater locations were positioned at the warm and dry edge of the central Sierran ellipsoid. Considering all sites in the main database, they fell in the upper $2.5 \%-10 \%$ quantiles for all measures, except January minimum temperature at Mono Craters, which was in the colder $25 \%$ of values.

White MTNS.-The final location is a set of 5 sites at the south end of the White Mtns. extending $8 \mathrm{~km}$ down Wyman Canyon, a major eastside canyon that debouches in Deep Springs Valley. Although pikas have been reported as abundant throughout higher elevations of the White Mtns. (Millar and Westfall 2010 and unpublished data; Robert Klinger, personal communication, 2013), here we report only the Wyman Canyon sites for their low elevation and arid/warm character. The first occupied sites encountered were near the canyon head at $\sim 2500 \mathrm{~m}$ on white dolomitic talus slopes of both north and south aspect. The exposures soon change to black Wyman sandstone with small talus patches (mean size $0.02 \mathrm{ha}$ ) that line both walls of the increasingly narrow canyon (Fig. 7). In July 2012 when we last visited, pikas and fresh hay piles were abundant in every talus investigated; only 5 scattered sites are recorded as representative. 


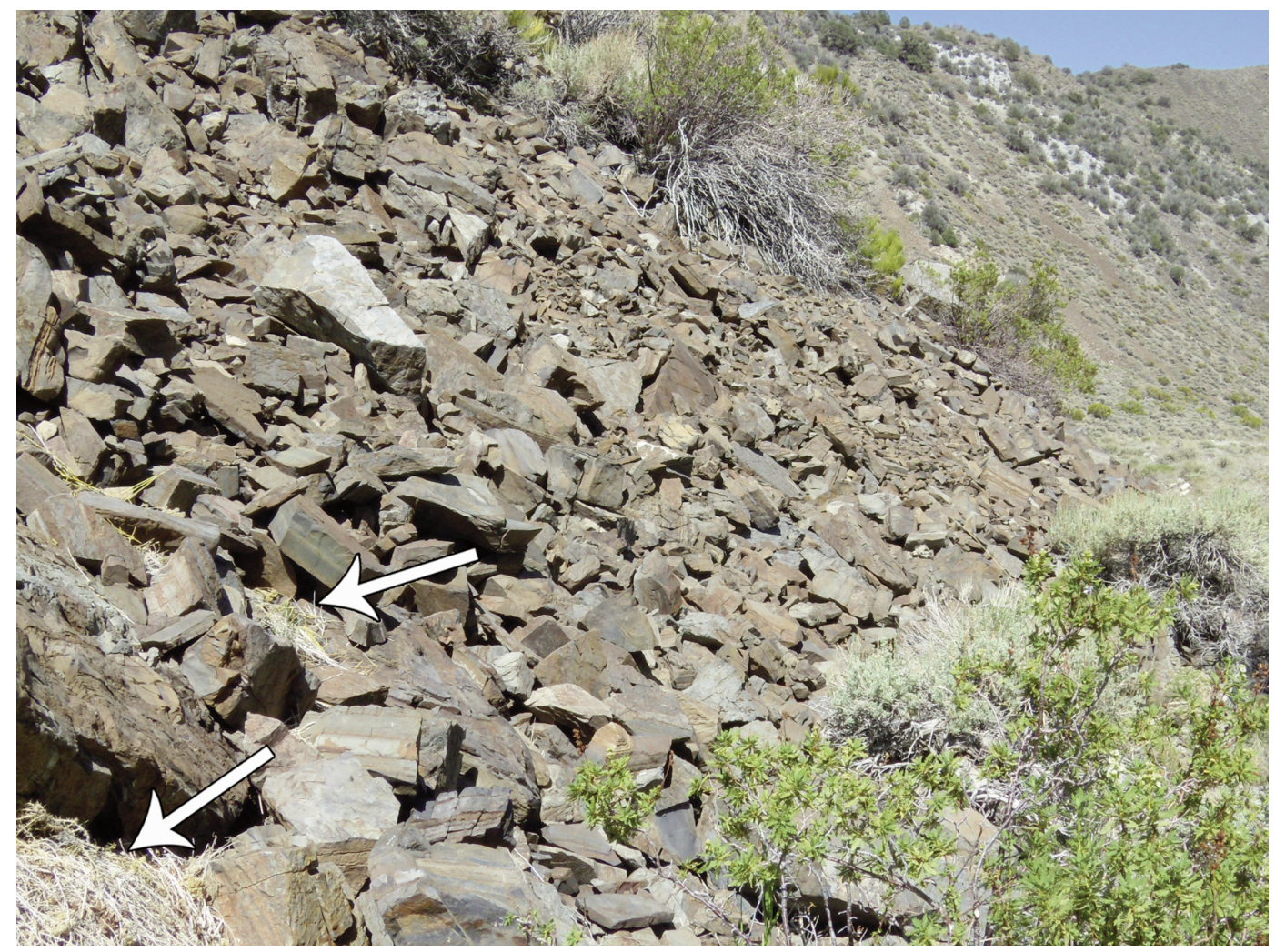

Fig. 7. Wyman Canyon, White Mtns. pika site. Taluses occupied by pikas occur on both aspects and extend at least $8 \mathrm{~km}$ down Wyman Canyon from $2854 \mathrm{~m}$ to Roberts Ranch at $2466 \mathrm{~m}$. Note 2 hay piles at arrows. View is east.

Hay piles within many of these taluses were separated by only $2-5 \mathrm{~m}$.

The lowest elevation examined in Wyman Canyon was at Roberts Ranch (2466 m), where pika activity was high. Talus continues downcanyon, so pikas potentially occur lower in the canyon. Over the elevation gradient of this canyon, vegetation grades from bristlecone pine forest at the upper portion through pinyonjuniper woodland to sagebrush shrub communities near Roberts Ranch. Shrub and herbaceous understory diversity changes accordingly, but common species in pika hay piles included sagebrush, rabbitbrush, fern bush (Chamaebatieria millefolium), perennial grasses, and, where taluses were adjacent to the riparian zone, Woods' rose, Ribes spp., and willows (Salix spp.). The abundant distribution of patches along the canyon is reflected in the linear distribution ("corridor") score at the local (0.5 km radius) scale. At the middle scale (2.5-km radius), coalescing canyons with abundant talus yield high habitat connectivity and large extent ("even" pattern). These lowland zones as a group, however, are relatively isolated from the abundant taluses at greater distance in the White Mtn. uplands.

The more interior Great Basin and southern location of the Wyman Canyon sites is reflected in the PRISM climate estimates, where winter temperatures are relatively cold for such low elevations, although still in the warmest $10 \%$ relative to all sites from the main database. Summers were relatively hot and precipitation very low $(448 \mathrm{~mm})$, second only to the MacDonald Peak location in northern California. The Wyman Canyon sites are positioned outside the White Mtn. ordination ellipse in the warm-dry direction and at the margin of the central Sierran ellipsoid.

\section{Discussion}

Twenty-one locations of occupied pika habitat comprising 46 pika-occurrence sites in the 
Great Basin of eastern California and western Nevada are described here for their marginal biogeographic, elevational, and/or climatic character. Some sites were included to document mountain ranges not reported previously. These 46 sites comprise a subset of sites encountered during the course of regional surveys. They span 9 mountain ranges from the Madeline Uplands in the north to the White Mtns. in the south and include elevations from $1848 \mathrm{~m}$ to $3392 \mathrm{~m}$. Landforms of pika habitats were diverse and included lava flows, anthropogenic ore dumps and road embankments, eroding bedrock and inselbergs, rock-glacier till, and typical granitic and metamorphic slope taluses. Aspects were diverse, but most (84\%) were southerly.

Locations below $2500 \mathrm{~m}$ have been considered unusual for pikas at Sierra Nevada and western Great Basin latitudes in recent decades (Smith 1974a, Smith and Weston 1990); even in the early 20th century, Sierran pika sites near and below $2500 \mathrm{~m}$ were reported as marginal (Grinnell and Storer 1924, Howell 1924, Sumner and Dixon 1953). More recently, however, occupied sites have been documented below this elevation. For instance, Millar and Westfall (2010) reported 10\% of 420 sites to be below $2500 \mathrm{~m}$; Stewart and Wright (2012) resurveyed historic pika sites in the northern Sierra Nevada and found 11 of 17 occupied sites to be below $2500 \mathrm{~m}$; and Beever et al. (2008) documented sites below $2500 \mathrm{~m}$ in the Hayes Canyon Range, northwest Nevada, which lies $50 \mathrm{~km}$ northeast of the sites in the Madeline Uplands.

As noted by these and other authors, though elevation is a general indicator of range limits, as a proxy for marginality it is often misleading. This presumably occurs for reasons related to talus area, quality, and connectivity, and for reasons related to meso- and microclimate, including variability due to aspect, coldair drainage, local meteorological processes related to topography, and internal talus thermal regimes. In particular, talus area effects are important near elevation margins, wherein pika population stability relates to local patch size, distance from related patches, and total proximal habitat area (Beever et al. 2003, 2010, 2011, 2013, Stewart and Wright 2012). In recent reviews of long-term studies, Beever et al. (2013) found that the amount of fieldverified habitat within each site remained the most consistent and important predictor of pika abundance.

Previous reports do not measure talus area effects at multiple scales relevant to pika metapopulation dynamics and distance for recolonization, which we attempt to address with a simple method in the current study. That is, population processes for pikas pertain to local patch relationships (talus distribution within $0.5 \mathrm{~km}$ of delineated sites), metapopulation processes within average pika dispersal range (talus distribution $0.5-2.5 \mathrm{~km}$ from sites), and inter-metapopulation dynamics (long-range dispersal, 2.5-5.0 km distances). The approach used here demonstrates how relationships can be easily assessed and compared at nested scales by using imagery (such as that from Google Earth) and a set of reference patterns. Limitations of the method include the likelihood of interobserver variability in assigning distribution patterns and the lack of exact fit of talus shape to idealized patterns.

An unexpected result from this exercise is that though occupied patches might appear remote or isolated in the field, this is often a function of one of the scales. For instance, a small patch might be solitary at the $0.5 \mathrm{~km}$ circular scale, but at distances of $2.5 \mathrm{~km}$, many more patches occur than are initially apparent (e.g., the Sweetwater sites in this study). By contrast, pika habitat can be abundant at the local scale, but when evaluated at radii of 2.5-5.0 km, habitat patches appear as islands (e.g., the Mono Crater sites). Further, many occupied patches reported here suggest a sink relationship to larger source populations, usually located in one direction from the marginal site. Additional study of these situations might reveal whether these marginal sites are selfsustaining or rely on colonization from larger metapopulation source areas for persistence.

Though a significant limitation of this schematic approach is lack of quantifying total area, the results suggest a need to focus future attention on distribution at multiple scales, thus moving toward greater precision than is achieved by use of undefined descriptors such as "remote" or "isolated." Describing and assessing marginality in this manner could help in understanding trends and vulnerability of populations at range limits.

Climatic constraints influence pika distribution and population viability, and these constraints are exacerbated in marginal populations, 
where patch size and habitat distribution are limiting (Stewart and Wright 2012). Smith (1974a) calculated mean maximum temperature from weather stations for June through September at low-elevation Bodie, California $(\sim 2500 \mathrm{~m})$, as $22.8^{\circ} \mathrm{C}$ with a mean of 43 days exceeding $25{ }^{\circ} \mathrm{C}$. That temperature is high compared to the mean maximum of $14.5^{\circ} \mathrm{C}$ (no days exceeding $25^{\circ} \mathrm{C}$ ) at a high-elevation population near Tioga Pass $(\sim 3200 \mathrm{~m})$. For 420 sites distributed broadly across the Sierra Nevada and western Great Basin, Millar and Westfall (2010) used the PRISM model to calculate a mean July maximum temperature of $19.3^{\circ} \mathrm{C}$ and a mean annual maximum temperature of $8.8^{\circ} \mathrm{C}$ (Table 3). The marginal locations described in this report had mean temperatures $4-5{ }^{\circ} \mathrm{C}$ warmer in summer and $3-4{ }^{\circ} \mathrm{C}$ warmer annually than found in the large dataset. Eleven of the 17 locations here had mean July maximum temperatures $\geq 22.8^{\circ} \mathrm{C}$ or in the upper $10 \%$ of the main database; 3 of 17 had means $\geq 25{ }^{\circ} \mathrm{C}$ or in the upper $2.5 \%$ of the main database; and all means were $>20.0$ ${ }^{\circ} \mathrm{C}$ or above the median. Thus, not only are the sites recorded here marginal (warm) relative to the broad distribution of pika locations but also warm relative to temperatures estimated for the well-known metapopulation near the species' warm limit in the Bodie Mining District. Similarly, precipitation at the reported locations was about half the value from the Millar and Westfall (2010) Sierra Nevada sites and similar to the mean for interior Great Basin sites (Table 3).

Several general locales described in this report have had historic reference as occupied pika habitat, including the Madeline Plain ("near Termo"; Howell 1924), the Wassuk Mtns. (Big Indian Mtn., 1947, cited in Beever et al. 2003; and multiple visits from 1994 to 2011, Beever et al. 2011), the Bodie Mtns. (in 1972, New York Hill, Smith personal communication 2010), Benjamin Buttes (Nichols 2009), and Mono Craters (Pumice Mine, 1969, 1990s, Smith personal communication 2009). Pikas are still extant in all but the Madeline Plain location. In the Madeline Plain, the historic reference appears to have been a very small set of talus patches on the Termo Buttes, and these comprise the sole habitat at distances $>5 \mathrm{~km}$ in all directions (an "island" at all scales in the current scheme). The highly inhospitable terrain of the playa surrounding this location appears, even under favorable climates, poorly suited for pika dispersal. Surveys in the peaks that surround the playa (Three Peaks, MacDonald Peak) showed abundant relict sign throughout the lower slopes and a large region of occupied patches on MacDonald Peak, extending to within $200 \mathrm{~m}$ elevation of the historic Termo reference. Surprisingly, the lowest of these patches, which has the warmest and driest climate of all the sites recorded, had the highest abundance of pikas in 2012, speculatively due to the fire-enriched herbaceous vegetation around the low talus compared to the limited forage of the higher old-growth sagebrush vegetation.

The sites described in this report further demonstrate the dietary flexibility of pikas. Though the pika is known to be a generalist forager and opportunistic in plant species selection, at any location some species are preferred and others are avoided altogether, likely for their relative water and nutritional values and/or because of plant defenses (Smith and Weston 1990). In general, pikas consume leaves and herbaceous stems over woody tissues, sclerophyllous or evergreen leaves, thorns or prickles, or tissues with strong chemical defenses (Smith and Weston 1990). By contrast, many of the species noted in hay piles of the marginal sites described here (and often the dominant species) are those with characteristics less often found in pika hay piles in this region. These include pinyon pine, Utah juniper, sagebrush, bitterbrush, mountain mahogany, Mormon tea, beavertail cactus, Ribes spp., fern bush, Woods' rose, desert peach, mule-ears, and prickly phlox, which might have been selected in these locations for chemical defense reasons.

In sum, study of marginal sites provides an opportunity to explore exceptions to the pika's range limits and to climatic, environmental, and dietary boundaries for the species. Exceptional populations conceivably will become more vulnerable in the future with continued climate change, and thus regular monitoring would be important in addressing conservation concerns and providing insight into critical threshold characters that trigger decline or enable persistence. Research focus on sourcesink relationships would help to clarify relationships of stable locations to those that are used transiently, and studies of the role of fire and pika forage quality would clarify the importance of vegetation diversity in promoting persistence of pikas at marginal locations. 


\section{ACKNOWLEDGMENTS}

We thank Don Grayson (University of Washington) and Joseph Stewart (University of Nevada, Reno) for critical reviews of the draft manuscript.

\section{Literature Cited}

Beever, E.A. 2002. Persistence of pikas in two low-elevation national monuments in the western United States. Park Science 21:23-29.

Beever, E.A., P.E. Brussard, and J. Berger. 2003. Patterns of extirpation among isolated populations of pikas (Ochotona princeps) in the Great Basin. Journal of Mammalogy 84:37-54.

Beever, E.A., X.Z. Dobrowski, J. Long, A.R. MynsBerge, AND N.B. Piekielek. 2013. Understanding relationships among abundance, extirpation, and climate at ecoregional scales. Ecology 94:1563-1571.

Beever, E.A., C. Ray, P.W. Mote, and J.L. Wilkening. 2010. Testing alternative models of climate-mediated extirpations. Ecological Applications 20:164-178.

Beever, E.A., C. Ray, J.L. Wilkening, P.F. Brussard, AND P.W. Моте. 2011. Contemporary climate change alters the pace and drivers of extinction. Global Change Biology 17:2054-2070.

Beever, E.A., J.L. Wilkening, D.E. McIvor, S.S. Weber, AND P.F. BRussard. 2008. American pikas (Ochotona princeps) in northwestern Nevada: a newly discovered population at a low-elevation site. Western North American Naturalist 68:8-14.

Bowers, R. 2009. Quaternary stratigraphy, geomorphology, and hydrologic history of pluvial Lake Madeline, Lassen County, northeastern California. Master's thesis, Humboldt State University, Department of Environmental Systems, Arcata, CA.

[CDFG] California Department of Fish and Game. 2013. Status review of the American pika (Ochotona princeps) in California. Report to the California Fish and Game Commission. 63 pp.

Calkins, M.T., E.A. Beever, K.G. Boykin, J.K. Frey, and M.C. Anderson. 2012. Not-so-splendid isolation: modeling climate-mediated range collapse of a montane mammal Ochotona princeps across numerous ecoregions. Ecography 35:780-791.

Collins, G.H., and B.T. Bauman. 2012. Distribution of low-elevation American pika populations in the northern Great Basin. Journal of Fish and Wildlife Management 3:311-318

Daly, C.R., R.P. Neilson, and D.L. Phillips. 1994. A statistical-topographic model for mapping climatological precipitation over mountain terrain. Journal of Applied Meteorology 33:140-158.

ERb, L.P., C. RaY, AND R. GURALnick. 2011. On the generality of a climate-mediated shift in the distribution of the American pika (Ochotona princeps). Ecology 92:1730-1735.

Fortin, M.-J., AND M.R.T. DALE. 2005. Spatial analysis: a guide for ecologists. Cambridge University Press, New York, NY.

French, H.M. 2007. The periglacial environment. Wiley $\&$ Sons, New York, NY. 458 pp.

Grayson, D.K. 2005. A brief history of Great Basin pikas. Journal of Biogeography 32:2103-2111.
Grinnell, J., and T.I. Storer. 1924. Animal life in the Yosemite. University of California Press, Berkeley, CA.

Hafner, D.J. 1994. Pikas and permafrost: Post-Wisconsin historical zoogeography of Ochotona in the southern Rocky Mountains, USA. Arctic and Alpine Research $26: 375-382$

Henry, P., A. Henry, and M.A. Russello. 2012. Variation in habitat characteristics of American pikas along an elevation gradient at their northern range margin. Northwest Science 86:346-350.

Howell, A.H. 1924. Revision of the American pikas. North American Fauna 47:1-57.

Lavin, M. 1983. Floristics of the upper Walker River, California and Nevada. Great Basin Naturalist 43: 93-130.

Manning, T., and J.C. Hagar. 2011. Use of non-alpine anthropogenic habitats by American pikas (Ochotona princeps) in western Oregon. Western North American Naturalist 71:106-112.

Meredith, S.J. 2002. The impact of habitat spatial structure on pika (Ochotona princeps) dispersal dynamics. Master's thesis, University of Nevada, Reno, NV. $62 \mathrm{pp}$.

Millar, C.I., C. Swanston, K. Heckman, K. Schmidt, R.D. Westfall, and D.L. Delany. Revision in review. Radiocarbon dating of fecal pellets from American pika (Ochotona princeps) provides new insights into population dynamics and climatic refugia. Ecological Applications.

Millar, C.I., and R.D. WestFall. 2010. Distribution and climatic relationships of the American pika (Ochotona princeps) in the Sierra Nevada and western Great Basin, U.S.A.: periglacial landforms as refugia in warming climates. Arctic, Antarctic, and Alpine Research 42:76-88.

Miller, C.D. 1985. Holocene eruptions at the Inyo Volcanic Chain, California: implications for possible eruptions in Long Valley Caldera. Geology 13:14-17.

Moritz, C., J.L. Patton, C.J. Conroy, J.L. Parra, G.C. White, AND S.R. BEISSINGER. 2008. Impact of a century of climate change on small-mammal communities in Yosemite National Park, USA. Science 322: 261-264.

Nichols, L. 2009. Recent extinctions and declines of American pika (Ochotona princeps) populations in the Bodie Hills of eastern California. Unpublished report to California Department of Fish and Game.

Peacock, M. 1997. Determining natal dispersal patterns in a population of North American pikas (Ochotona princeps) using direct mark-resight and indirect genetic methods. Behavioral Ecology 8:340-350.

Rodhouse, T.J., E.A. Beever, L.K. Garrett, K.M. Irvine, M.R. Jeffreess, M. Munts, and C. Ray. 2010. Distribution of American pikas in a low-elevation lava landscape: conservation implications from the range periphery. Journal of Mammalogy 91:1287-1299.

SAS Institute, InC. 2010. JMP ${ }^{\circledR}$ 9.01. SAS Institute, Inc., Cary, NC.

Simpson, W.G. 2009. American pikas inhabit low-elevation sites outside the species' previously described bioclimatic envelope. Western North American Naturalist 69:243-250.

SMith, A.T. 1974a. Distribution and dispersal of pikas: influence of behavior and climate. Ecology 55: $1368-1376$. 
1974b. The distribution and dispersal of pikas: consequences of insular population structure. Ecology 55:1112-1119.

Smith, A.T., AND M. GILPIN. 1997. Spatially correlated dynamics in a pika metapopulation. Pages $407-428$ in I.A. Hanski and M. Gilpin, editors, Metapopulation biology: ecology, genetics, and evolution. Academic Press, San Diego, CA. 521 pp.

Smith, A.T., AND M.L. Weston. 1990. Ochotona princeps. Mammalian Species 352:1-8.

Stewart, S.A.E., and D.H. Wright. 2012. Assessing persistence of the American pika at historic localities in California's northern Sierra Nevada. Wildlife Society Bulletin 36:759-764.

Sumner, L., AND J.S. Dixon. 1953. Birds and mammals of the Sierra Nevada. University of California Press, Berkeley, CA.
[USFWS] United States Fish and Wildlife Service. 2010. Endangered and threatened wildlife and plants: 12-month finding on a petition to list the American pika as threatened or endangered. Federal Register 50 CFR Part 17 [FWS-R6-ES-2009-0021 MO 92210-0-0010]. 34 pp.

Wilkening, J.L., C. Ray, E.A. Beever, and P.F. BrusSARD. 2011. Modeling contemporary range retraction in Great Basin pikas (Ochotona princeps) using data on microclimate and microhabitat. Quaternary International 235:77-88.

Received 7 February 2013 Accepted 16 August 2013 